\title{
Bokser i śmierć - udana słowacko-polska koprodukcja filmowa, do której nie doszło
}

Nie ma powodu, aby wątpić w sens realizowania międzynarodowych koprodukcji filmowych we współczesnej Europie. Podobnie jak w przeszłości, są one sposobem koncentracji sił twórczych, wszechstronnej synergii i przede wszystkim inwestowania połączonych funduszy, zwłaszcza gdy nie rysują się perspektywy zwrotu kosztów. Uzasadnione są jednak obawy, że powstanie mieszanka, z której wyparuje indywidualność, niepowtarzalność dzieła, ponieważ film musi spełnić kryteria i oczekiwania kooperujących stron.

Słowaccy filmowcy, ze względu na powiązania historyczne i niewielką barierę językową, angażują się w liczne międzynarodowe projekty zwłaszcza z Republiką Czeską. Problem w tym, że za „,słowacki” uważa się każdy tytuł z jakimkolwiek - choćby minimalnym - wkładem koprodukcyjnym. Jako filmy słowackie honorowane więc były najważniejszą krajową nagrodą „Słońce w sieci” Ja, Olga Hepnarova (Já, Olga Hepnarová, 2016, reż. Tomáš Weinreb, Petr Kazda) czy Masaryk (2016, reż. Julius Ševčík); z punktu widzenia Bratysławy również Pokot (2017) Agnieszki Holland może być nominowany do tej nagrody. Takie spojrzenie na potencjał kinematografii narodowej jest $\mathrm{z}$ gruntu fałszywe, niezależnie od tego jak korzystnie wyglądają liczby i jak miłe są nagrody festiwalowe.

\section{Bokser i śmierć w kiosku z gazetami}

Współpraca przy realizacji filmu nie musi być jedynie powodem do kalkulacji, spekulacji i, w lepszym przypadku, oszczędnego wydawania środków. Może posiadać głębszy sens. Istnieje eksplicytny przykład współpracy koprodukcyjnej z przeszłości. Jakkolwiek - de iure - do niej nie doszło. Chodzi o słowacko-(czechosłowacko)-polsko-niemiecką (wschodnio-niemiecką) kooperację przy filmie Bokser i śmierć (1962) Petera Solana, której nie udało się zrealizować w pełnowymiarowym trybie koprodukcyjnym,

\footnotetext{
* Uniwersytet św. Cyryla i Metodego w Trnawie.
} 
a „zaledwie” w ramach dobrej współpracy w oparciu, by tak rzec, o międzyludzką profesjonalną bazę: ponadgraniczną pracę nad scenariuszem i powierzenie głównych oraz drugoplanowych ról międzynarodowej obsadzie. Obok Słowaka Štefana Kvietika w głównej roli Kominka, jako komendant obozu zabłysnął popularny niemiecki aktor Manfred Krug (1937-2016). W rolę ordynansa Williego wcielił się inny niemiecki aktor Edwin Marian (Marian Kmieczak, urodzony w 1928 roku i wychowany w Łodzi). Kapitana Holdera grał również niemiecki aktor, Gerhard Rachold. Polakom powierzono istotne role drugoplanowe: Józef Kondrat wystąpił jako Węźlak, Staszka zagrał Edmund Ogrodziński, innego więźnia Emila - Janusz Bobek.

Historia narodzin tego filmu jest wymowna i pouczająca pod wieloma względami. Był rok 1958 i przy okazji pierwszej twórczej współpracy spotkało się dwóch młodych słowackich filmowców, absolwentów praskiej FAMU - reżyser i scenarzysta Peter Solan ${ }^{1}$ oraz Tibor Vichta ${ }^{2}$. Reżyser po latach wyznaje:

Poleciłem mu [chodzi o Vichtę - przyp. aut.] jedno opowiadanie, które zupełnie przypadkowo znalazłem w takim kieszonkowym wydaniu opowiadań sportowych. Była w nim mowa o więźniu, którego wybrał sobie komendant obozu jako sparring partnera. Ten komendant, jako były bokser ma nadzieję, że po wojnie - wygranej oczywiście dla Niemców - wróci do boksu. Chodzi o to, by nie wyszedł z formy.

Okazało się, że autorem jest Polak. Jakoś nawiązaliśmy współpracę z Polakami, to był przyjemny okres, relatywnie znośny po'56. Zabraliśmy się za to i w'58 scenariusz był gotowy ${ }^{3}$.

Przy innej okazji spotkanie z tekstem opowiadania wspomina Solan w ten sposób:

W'56 w kiosku z gazetami kupiłem sobie książkę Opowiadania sportowe. Przeczytałem w niej między innymi i opowiadanie Bokser i śmierć polskiego pisarza Józefa Hena ${ }^{4}$.

\footnotetext{
${ }^{1}$ Peter Solan - słowacki reżyser filmowy (1929-2013).

2 Tibor Vichta - słowacki dramaturg i scenarzysta (1933-1991).

${ }^{3}$ Cytowane z filmu dokumentalnego o Tiborze Vichcie Kým sa skončí tento film (Zanim skończy się ten film, 2009, reż. Tomáš Hučko).

${ }^{4}$ Pamięć po latach, co jest naturalne, zawodzi reżysera - nie jest on precyzyjny w datach. W roku 1956 opowiadanie Bokser i śmierć pojawiło się najpierw w Polsce, w zbiorze opowiadań Cud z chlebem. W Czechosłowacji tekst ukazał się dopiero w 1958 roku i to dwukrotnie. Najpierw samodzielnie, w czterdziestostronicowej broszurze wydawnictwa Šport Bratislava, pod dość szczególnym tytułem Jarmok športových senzácií (Jarmark sensacji sportowych). W tym samym roku ukazał się w przekładzie czeskim pełny zbiór opowiadań Józefa Hena Zázrak s chlebem (Cud z chlebem); znalazło się w nim również wspomniane opowiadanie, które opublikowało wydawnictwo Naše vojsko.
} 
Dopiero po kilku tygodniach obudziłem się nagle w środku nocy z myślą, że właśnie to jest temat, nad którym chciałbym popracować. Dałem tę historię do czytania Tiborowi Vichcie, który zgodził się, że Bokser i śmierć może być ciekawym filmem. Wkrótce nasz scenariusz został odrzucony z powodów ideologicznych ${ }^{5}$.

Wspomniane przez Solana odrzucenie scenariusza było dopiero początkiem skomplikowanej historii. Praktykę zatwierdzania scenariuszy w ówczesnej słowackiej kinematografii, trafnie ilustrowaną właśnie przypadkiem filmu Bokser $i$ śmierć, omawiał słowacki dramaturg Peter Karvaš w artykule zamieszczonym w „Rudym právie”. ${ }^{6}$. Krytyczny tekst Karvaša był na tamte czasy nieoczekiwanie odważny, chociaż formułowany raczej dyplomatycznie. Z jego lektury nie dowiemy się jednak, kto konkretnie zakazywał realizacji projektu ${ }^{7}$, do którego scenariusz napisano w 1958 roku. We wrześniu 1959 roku, pomimo zakazu Pavla Dubovskiego, dyrektora Centralnego Zarządu Filmu Słowackiego, Rada Artystyczna scenariusz jednak zatwierdziła ${ }^{8}$. Do kin film wszedł dopiero w 1963 roku.

\section{Józef Hen}

Wkrótce po rozpoczęciu kariery pisarskiej Józef Hen dał się poznać jako scenarzysta filmów, które wpisują się w historię Polskiej Szkoły Filmowej. Znamienne, że na stronie poświęconej kulturze polskiej, w jego haśle biograficznym nie wspomina się o współpracy ze Słowakami, a scenariusz fabuły Bokser $i$ śmierć jest mu przy pisany w całości. Hen współpracował przy wielu polskich filmach:

${ }^{5}$ Slovenský film 60. rokov: Boxer a smrt', DVD edícia Slovenského filmového ústavu a denníka Sme. Časopis DVD edície 04, s. 10.

${ }^{6}$ Peter Karvaš, Nejen tento film, „Rudé právo” 27.01.1963, s. 2.

7 Symptomatyczne jest, że autor najpierw wymienia organy, które „w krytycznej chwili" stanęły w obronie filmu (podstawowa organizacja partyjna Komunistycznej Partii Słowacji w Filmie Słowackim oraz Zarząd Główny Czechosłowackiego Związku Młodzieży: szło o dzieło młodych), a dopiero później wspomina o organach zatwierdzających (w liczbie mnogiej), w których przecież „,...] zasiadają konkretni ludzie, mający jakieś imiona i nazwiska, miejsca pracy, adresy [...]. Wydaje się, że konieczne jest, by raz na zawsze skończyć z anonimowością uchwał rad artystycznych, kolegiów redakcyjnych i innych organów zatwierdzających w dziedzinie teatru, filmu i literatury" (tamże).

${ }^{8}$ Václav Macek, Jelena Paštéková, Dejiny slovenskej kinematografie, Vydavatel’stvo Osveta, Martin 1997, s. 188. 
W latach 50. i 60. (po odwilży, a przed rokiem '68) Hen zajął się także pisaniem scenariuszy na podstawie swojej prozy; powstały w tym czasie m.in. filmy Krzyż Walecznych i Nikt nie woła w reżyserii Kazimierza Kutza, Dwa żebra Adama w reżyserii Janusza Morgensterna, a także Kwiecień, Prawo i pięść oraz Bitwa o Kozi Dwór ${ }^{9}$.

W swoich wypowiedziach Hen wspomina również o zainteresowaniu studia Kadr adaptacją opowiadania Bokser i śmierć (a w tym kontekście wymienił również nazwisko Andrzeja Wajdy) ${ }^{10}$, ale kiedy odezwali się Słowacy, uznał, że „lepszy wróbel w garści” i tak doszło do komunikacji transgranicznej w sprawie realizacji filmu.

Dokumentuje tę okoliczność krótka rozmowa zamieszczona w bratysławskim tabloidzie:

Zawiadomiono redakcję, że w hotelu Carlton w pokoju nr 537 mieszka polski pisarz Józef Hen, który napisał scenariusz do nowego filmu słowackiego. Nic więcej. Poszliśmy do niego, jedną nogą był już w - wannie, kiedy mu przeszkodziliśmy. Pozwolił na to i był chętny do rozmowy $z$ nami $[\ldots]$

- Słyszeliśmy, że napisał Pan scenariusz do nowego słowackiego filmu?

- Tak, właśnie z tego powodu przyjechałem do Bratysławy [...] [opowiadanie] spodobało się reżyserowi P. Solanowi, który napisał mi, że chętnie by je ekranizował. W listopadzie zeszłego roku napisałem scenariusz i teraz przedyskutowaliśmy go z J. Mináčem, P. Solanem, J. Oravcem, M. Gajdošovą i T. Vichtą ${ }^{11}$. Trzeba zaznaczyć, że ten ostatni współpracował przy moim scenariuszu. [...]

- Kiedy rozpocznie się realizacja?

- Tego jeszcze nie wiem. Ważne, że scenariusz już zatwierdzono ${ }^{12}$.

Według arkusza danych produkcyjnych ${ }^{13}$ scenariusz literacki został zatwierdzony przez Radę Artystyczną w dniu 5 września 1959 roku. Jednakże do realizacji nie doszło tak szybko. Pierwszy dzień zdjęciowy w studiu to 29 czerwca 1962 roku, czyli prawie trzy lata po zatwierdzeniu projektu. Dlaczego ta realizacja tak bardzo przesunęła się w czasie i co działo się z projektem?

${ }^{9}$ JózefHen. Życie i twórczość, http://culture.pl/pl/tworca/jozef-hen (dostęp: 26.05.2017).

10 Wspomina o tym Martin Kaňuch w tekście Podoby zvierat'a, stopy l'udskosti (Formy zwierząt, ślady ludzi), [w:] Slovenský film 60. rokov Boxer a smrt', s. 13.

11 Pracownicy dramaturgii w Studio Filmowym na Kolibie, Monika Gajdošová była dramaturgiem projektu.

12 Boxer a smrt’ vo filme, „Večerník” 17.09.1959.

${ }^{13}$ Výrobný list filmu Boxer a smrt', archiwum Biblioteki SFÚ (Slovenský filmový ústav - Słowacki Instytut Filmowy). 


\section{Polsko-słowacka koprodukcja, do której nie doszło}

Myśl o wspólnej realizacji filmu towarzyszyła polskim i słowackim twórcom od samego początku. Jednak wyobrażenia na temat zakresu i tempa współpracy były mocno nierealistyczne. Rzeczywistość okazała się o wiele bardziej skomplikowana niż przypuszczali twórcy. Mimo że formalnie Bokser i śmierć jest wyłącznie filmem słowackim, to międzynarodowy charakter jego realizacji znacząco przyczynił się do rangi, wartości i ostatecznie - sukcesu filmu.

Wypada odpowiedzieć na dwa pytania: jaki sens mogła mieć koprodukcja i dlaczego szanse na jej uskutecznienie były minimalne? Zaproszenie Polaków do pracy nad adaptacją prozy polskiego pisarza wydawało się oczywiste. Innym ważnym powodem podjęcia rozmów ze stroną polską był ciężar gatunkowy, a jednocześnie kwestia wyczucia w odniesieniu do filmowego przepracowania tematu obozu koncentracyjnego, jego realiów, zasad, które w nim rządziły. Za film, który wysoko postawił poprzeczkę wszystkim twórcom zamierzającym zrealizować film o Holocauście, wciąż unawano Ostatni etap (1948) Wandy Jakubowskiej. Ustanowił on pewien poziom, który jeszcze wówczas zobowiązywa1 ${ }^{14}$. Nawiązano więc kontakty i Jakubowska miała sprawować kuratelę nad przygotowywanym filmem. Koncepcja Hena i Vichty spotkała się jednak z jej krytyką. Różnice w ujęciu tematu przyczyniły się również do perypetii z zatwierdzeniem projektu i tak, paradoksalnie, pierwotne przesłanki koprodukcji szybko stały się barierą dla współpracy.

$\mathrm{W}$ czasie powstawania projektu w sposób wymowny wyraził to reżyser:

Do pewnego stopnia rozumiem moich oponentów, niektórzy z nich przeżyli obóz koncentracyjny, mieli swoje osobiste doświadczenia oraz przeżycia i postrzegali te rzeczy inaczej. Nie chodziło mi o dokumentalną rejestrację faktów, ułożonych mozaikowo, tak jak, powiedzmy, zrobiła to Wanda Jakubowska w Oświęcimiu. Właśnie ona miała sprawować nadzór nad moim filmem, ale nie doszliśmy do porozumienia, ponieważ ona widziała sprawy tak, jak je przeżyła. Mnie zależało na spojrzeniu współczesnym i ich przewartościowaniu. Faszystów nie możemy nadal ukazywać jako wyłącznie złych straszydeł, dla dzisiejszego młodego widza trzeba już wydobyć filozoficzne przesłanie ${ }^{15}$.

${ }^{14}$ Obraz obozu koncentracyjnego w filmie Jakubowskiej uległ z czasem krytycznemu przewartościowaniu, na pierwotną wizję wpłynęła szczególnie silna motywacja ideologiczna.

15 Richard Blech, Boxerov zápas nebol márny, „Film a divadlo” 28.02.1963, nr 5, s. 5. 
W koprodukcyjnej motywacji niemniej ważną rolę mógł odegrać także respekt wobec bardziej rozwiniętej polskiej kinematografii. W dobrze poinformowanych słowackich kręgach filmowych kultura północnych sąsiadów cieszyła się szacunkiem (Polska Szkoła Filmowa była uznanym za granicą fenomenem). Choć przepływ informacji był profilowany przez odpowiednie filtry (pomimo deklarowanych zasad wspólnego obozu socjalistycznego treści były zazdrośnie strzeżone i kontrolowane), zainteresowane gremia wysoko ceniły dzieła Szkoły Polskiej czy tak zwaną czarną serię w polskim dokumencie. Planowana koprodukcja mogła w intencjach twórców słowackich stać się sposobnością uczestnictwa $w$ idących $\mathrm{z}$ duchem czasu trendach, szansą na inspirowanie się tym, co progresywne.

\section{Jakie są warunki nawiązania współpracy międzynarodowej?}

Koprodukcja z zasady wiąże się ze złożonym, głównie administracyjno-finansowym i produkcyjnym zestawem problemów, z którymi kinematografia słowacka nie miała wtedy większych doświadczeń. Od końca wojny powstały dwa filmy $\mathrm{w}$ ramach takiego trybu: słowacko-węgierska komedia kostiumowa Parasol świętego Piotra (Szent Péter esernyőjelDáždnik svätého Petra, 1958, reż. Frigyes Bán, Vladislav Pavlovič) i wpisująca się w mit wyzwoleńczy czechosłowacko-gruzińska Przerwana pieśń (Prervannaya pesnya/Přerušená píeseň, 1960, reż. Nikolaj Konstantinovič Sanišvili, František Žáček).

Jak na tym tle miałaby wyglądać współpraca z Polską, w której nie wywietrzała jeszcze wówczas atmosfera roku'56, masowych ruchów społecznych i następującego po nich kursu reform Władysława Gomułki? Chociaż Polska była integralną częścią bloku wschodniego, w oczach przywódców sąsiednich krajów była partnerem niepewnym, podejrzanym.

Jest zatem zrozumiałe, że $\mathrm{w}$ przypadku filmu Bokser $i$ śmierć pierwotna wizja koprodukcji szybko stała się iluzją. Ponadto do koprodukcji potrzeba co najmniej dwóch partnerów, a strona polska nie miała szczególnego powodu, aby angażować się w projekt. Gwoździem do trumny był udział młodych autorów, absolwentów praskiej FAMU, odpowiednio wykształconych, ale bez doświadczenia. Ich nastawienie było inne niż ustalona praktyka, wygodna rutyna studia na Kolibie, według której działał mechanizm kinematografii. 


\section{Pierwsza słowacka generacja z FAMU}

W porównaniu z Polską czy Węgrami Czechosłowacja - dzięki niewspółmiernie lepszej sytuacji gospodarczej - uniknęła większego szoku destalinizacji w roku 1956. Żądania polityczne pojawiały się tylko w czasie posiedzeń Związku Pisarzy czy w ramach aktywności środowiska studenckiego. $\mathrm{W}$ tej sytuacji $\mathrm{w}$ latach 50 . na profesjonalną scenę $\mathrm{w}$ kinematografii wkracza pierwsza wykształcona na FAMU generacja twórców, którzy studiowali przede wszystkim reżyserię ${ }^{16}$. W praktyce, dążąc do urzeczywistnienia swoich wizji, napotykają na trudności, które często urastają do fundamentalnych konfliktów z kierownictwem struktur filmowych.

\section{„Profaszystowski” film}

Zastrzeżenia decydentów skumulowały się w jednym znaczącym zarzucie: istnieje niebezpieczeństwo, że obraz wroga nie będzie jednoznaczny, czyli absolutnie negatywny. Reżyser wspomina tę sytuację:

W najwyższych instancjach w 1958 roku osądzono, że jest to profaszystowski film. Kiedy Niemiec udaje, że gra fair play, dla nich oznaczało to, że ukazujemy dobrego Niemca. Ze scenarzystą Tiborem Vichtą nie chcieliśmy się poddać, bo byliśmy naiwni i nie chciało nam się wierzyć, że oni tak myślą poważnie. Ale oni myśleli poważnie ${ }^{17}$.

Po udanej premierze gotowego filmu Pavol Branko analizował epopeję z zatwierdzeniem scenariusza:

Trzy lata scenariusz tego filmu przerzucano z szuflady do szuflady, wędrował z organu do organu, a jego twórcy za nic nie mogli dobrnąć do "finále", zyskać placet na realizację. I to właśnie w okresie, gdy kinematografia słowacka produkowała ten najuboższy repertuar poniżej średniej, gdy bez walki i bez oporu trafiały do produkcji scenariusze, w których nie było nic podejrzanego i wątpliwego, wręcz przeciwnie, wszystko było jasne od początku, że są zupełnie niekontrowersyjne, ale i bezproblemowe - projekty poronionych filmów ${ }^{18}$.

16 Do pierwszych absolwentów FAMU należy w roku 1950 kończący wówczas studia Stanislav Barabáš, grupę zamyka Tibor Vichta, absolwent z roku 1957. W międzyczasie w Pradze studiowali wszyscy wielcy pierwszej profesjonalnej generacji twórców: Martin Hollý, Štefan Uher, Peter Solan, Eduard Grečner i inni.

17 Slovenský film 60. rokov: Boxer a smrt', s. 10.

18 Pavol Branko, V ringu s handicapom, „Kultúrny život” 1963, nr 9, s. 8. 
Kierownictwo kinematografii zbyt długo nie mogło pojąć (bardziej prawdopodobne - nie chciało), że architektonika tej historii z udawanym sportowym fair play w relacji komendant obozu-więzień stanowi z jednej strony doskonałą ramę dramaturgiczną dla niezwykle sugestywnego, oryginalnego (nie cliché) nakreślenia potworności faszyzmu, a z drugiej - jest wymagającą wyczucia sposobnością ucieleśnienia takich wartości, jak godność człowieka, wiara w dobroć i ludzką solidarność. Opowiedziany w filmie epizod z obozu koncentracyjnego jest czymś więcej niż sprawozdaniem z kuriozalnego pomysłu esesmana-,,sportowca", ukonkretnionym na tle realiów obozu. Staje się uniwersalną wypowiedzią o odwiecznej walce Zła (w aktualnym wydaniu totalitarnej, faszystowskiej władzy) z ideałami wolności i wartościami humanizmu. Branko dodaje:

Co to właściwie była za heretycka myśl, która do tego stopnia wyostrzyła ostrożność
i wzmogła obawy, że trzy lata wstrzymywano twórców, by ją wyartykułowali? Takie
pułapki były znamienne raczej dla tekstów odnoszących się do współczesności niż
dla wątków, by tak rzec, już historycznych, czerpiących z czasów II wojny świato-
wej, z obozów nazistowskich, przetworzonych przez naszą sztukę dziesiątki razy?
Ale okazuje się, że to tylko złudzenie i że to nie obecne czasy produkują zwiększone
alergie, ale przede wszystkim aktualność i waga przywołanych problemów. Ale jeśli
idea zmierza w kierunku współczesności, kiedy przygląda się przeszłości z dzisiej-
szego punktu widzenia, nagle i ona staję się paląca, ,delikatna”. Przecież jednak tyl-
ko obecność takich fermentów w dziele artystycznym, czyli tego, co jest w materiale
z przeszłości „delikatne”, ponieważ aktualne, jeszcze nierozwiązane, bez odpowiedzi
- cywilnie zezwala na jego stworzenie, jeżeli tylko artystom nie chodziło o ucieczkę
od problemów swoich czasów ${ }^{19}$.

Wreszcie wczesnym latem 1962 roku realizacja filmu Bokser $i$ śmierć otrzymała zielone światło, a reżyser Solan - z ostrzeżeniem, że absolutnie musi nakręcić dobry film - mógł przystąpić do zdjęć. Kolaudacja odbyła się 20 grudnia 1962 roku. Peter Solan wspomina po latach:

Na projekcję tej pierwszej kopii przyszło całe naczalstwo z KC. Pozwolili mi - chyba przez pomyłkę - być przy tym. Nie, zaprosił mnie Gejdoš, był wtedy szefem. Film wyświetlono, w pierwszym rzędzie siedział Bacílek ${ }^{20}$, nogi trzymał w górze, bolały go. Była tam większość przeciwników filmu z KC i kilku - dwóch, trzech, którzy mu kibicowali. No i po projekcji nastała straszna cisza. Taka minuta - długa minuta moje-

19 Tamże.

${ }^{20}$ Karol Bacílek (1896-1974) - komunistyczny urzędnik, w latach powojennych pełnił znaczące funkcje polityczne, na Słowacji, w latach 1953-1963 był pierwszym sekretarzem KC KPS. 
go życia. Bacílek wygłosił tą swoją piękną czechosłowacczyzna, że „wiecie, kiedy byłem na Čiernym Balogu, i tam był jeden Niemiec, chociaż grał na pianinie, a dobrze, ale była to świnia! I ten tutaj to świnia! Fuuuj...". Od razu zadzwoniłem do Tibora, mówię mu: dobrze to się skończyło, oni to kupili! A on mi odpowiedział: Ale innym razem nie kupią. I miał rację ${ }^{21}$.

\section{Opowiadanie - scenariusz - film}

W roku 2014 Jakub Radomski zapytał Hena o źródło opowiadania Bokser i śmierć. Pisarz barwnie przybliża proces powstawania dzieła literackiego, które czerpie z elementów rzeczywistości:

Czy Kominek to postać autentyczna? W pana opowiadaniu Bokser i śmierć jest bokserem, który trafia do obozu koncentracyjnego i udaje mu się przeżyć tylko dlatego, że został sparring partnerem komendanta obozu Waltera Krafta, w tamtych czasach czołowego pięściarza Europy.

Józef Hen: Ci dwaj bohaterowie to połączenie kilku historii, które słyszałem. Teddy Pietrzykowski ${ }^{22}$, polski bokser, rzeczywiście trenował lagerführera i zaraz po wojnie zaczęło mi to krążyć po głowie. Ale musiałem jeszcze stworzyć postać Niemca i tutaj pomogła mi osoba Maxa Schmellinga, który przed wojną był nawet mistrzem świata, nokautował słynnego Joe Louisa, a później chciał odzyskać swój tytuł i nie pozwalano mu na to ${ }^{23}$.

Przyjrzyjmy się jednak adaptacji tego dzieła. W ramach procesu twórczego (i procesu zatwierdzania projektu) powstało aż osiem wersji scenariusza ${ }^{24}$. Ze spuścizny scenarzysty i dramaturga Tibora Vichty udało się otrzymać ciekawy materiał archiwalny - scenariusz literacki filmu oznaczony na obwolucie rzymską dwójką (czyżby druga wersja?). Tekst pochodzi z lipca 1960 roku, czyli powstał akurat w połowie całego procesu adaptowania i zatwierdzania oraz jest wewnętrznym, roboczym materiałem Drugiej Grupy Twórczej Studia Filmów Fabularnych w Bratysławie na Kolibie. Wymienieni są w nim autorzy: Józef Hen, Tibor Vichta, Peter Solan, a jako dramaturg występuje Monika Gajdošová.

${ }^{21}$ Cytowane z dokumentu Kým sa skončí tento film.

${ }^{22}$ O losach słynnego więźnia nr 77 z Auschwitz: Marta Bogacka, Bokser z Auschwitz: losy Tadeusza Pietrzykowskiego, Demart SA, Warszawa 2012 (przyp. T. H.).

${ }^{23}$ Józef Hen, Kiedyś oszustów w sporcie było mniej, http://www.przegladsportowy.pl/ inne-dyscypliny,jozef-hen-kiedys-oszustow-w-sporcie-bylo-mniej,artykul,472898,1,307. html (dostęp: 2.05.2017).

${ }^{24}$ Podaję za: Slovenský film 60. rokov: Boxer a smrt', s. 5. 
29. obraz。

\section{Kraftova pracovña.}

Major zdvihne hlavu:

- Prečo ste ho nezlikvidovali?

Holder privrie oči: Ľahký ironický úsmev ma prikryje ústa.

- To by bolo, Herr major, to najlohsie,

Kraft sa na neho zvedavo zadíva.

- Ľahko sa mohlo stat, - pokračuje Holder, - že ten väzeň by sa bol škeril do ústia revolvemu ako nahlúply vidiečan do objertívu.

Major sa zasmeje:

- Mám hádam režírovat posledné chvíle väzñov?

- He by patom väzni prijímali smrt ako vylápenio, ako hioto niekú rutrast, ake yúbon - tok ánol Keả sme už pri divadle. 'sám tri mesiace režírujete tú operetu. \& Komínkd sq2 ftśva/subreta. Je to len otázka času, kým mu ostatní väzni nezačnú do ringu posielat kytice.

Kraft sa smeje: Bujaro, bezuzdne.

Fy by-sto $\forall$ toj openate radi robili septára, nio?

Holder pol obráti sa k obloku, pozerá dolu, na robotujúcich väzñov.

Kraft $\mathrm{k}$ nemu pristúpi.

- Viete, na čo riyslia? - spýta sa Holder. - Na človeka, ktorj́

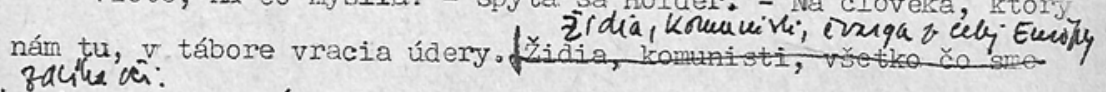

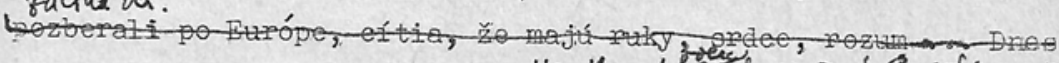

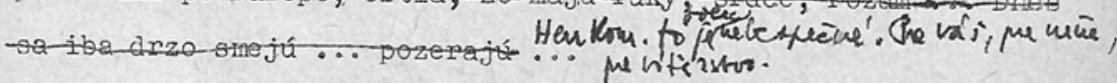

Major vytiahne tažkú parabelu. Nahodí si ju v muke. Zamieri.

Treskne výstrel.

Jeden Z Z väzňov zoștane ležat, ostatní sa rozutekajú ako za,jaco. - Wât tí taśi korounistiat - spýta sa Kraft si tichou vít’azoslávnostiou $\mathrm{v}$ hlase. 

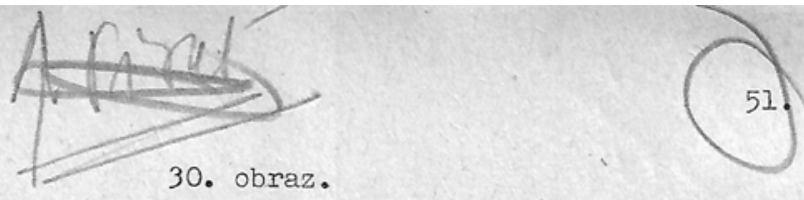

Venžlákova izba.

Staškova bledá, bolestne sústredená tvár. V1hké, víčkami slabo prikryté oči.

- Nevládzem, nerozpamätám sa!

Venžlák mu chlácholivo prejde rukou po pleci.

- Skusíme ešte raz, - povie mierne.

Stašek privrie oči. Dobre.

Okolo stojí pät-šest väzňov. Všetci sa na Staška pozerajú s porozumením.

- Vieš, ako dôležité sú tie slová. Od nich závisi tvoj g Málo

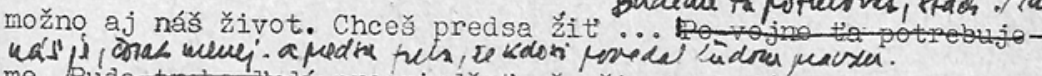

me. Bude treba ludf presvieděat, ž život stoji ze to, aby sa žil a že ho treba zmenitic Sústreä sa! Mier, priatelłstrol, socia-

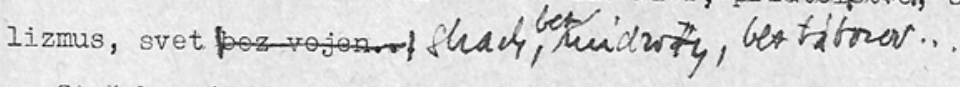

Stašek vníma, pozorne načúva. Nie je to ono.

- Aké to boli slová? - spýta sa ktorýsi väzeñ.

Stašek sa na neho placho usmeje:

- Prosté! Ani mi nepripadali ako heslo. Poredalo ich plavé

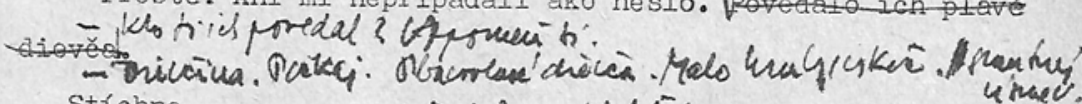

Stichne.

$$
\text { - Es lo movolit }
$$

- Dievča, - opakuje venžlár, - Áiska prvý pohted, rodina,

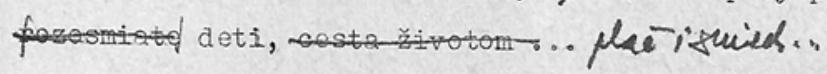

Stašek krúti hlavou.

Do cintay

Venžlák pozrie po ostatných väzňov:

7 Pre anešok stacı!

Od dverí sa ozve zakašl’anie, varovné znamenie. Väzni sa rozpŕchnu na prične. Pri stole zostane len Venžlák.

Do miestnosti vojde Komínek.

Fot. 1 i 2. Scenariusz filmu Bokser i śmierć (1962) z odręcznymi poprawkami scenarzysty Tibora Vichty. Z prywatnego archiwum Dagmary Ditrichovej 
Scenariusz zawiera 115 stron tekstu formatu A4. Jest napisany w języku słowackim, w tym też języku nakreślono wszystkie dialogi bohaterów różnych narodowości: niemieckiego komendanta Krafta, Helgi, doktora Glucha, Holdera, Williego, polskiego towarzysza z celi Węźlaka i Staszka, ale także wszystkich pozostałych, którzy w filmie mówią każdy własnym językiem. Zawartość jest rozpisana na 65 ujęć, nierozłożonych na prawą i lewą stronę (obraz-dźwięk), dialogi są częścią tekstu literackiego. Maszynopisowi towarzyszą obfite odręczne notatki Tibora Vichty, które często wprowadzają istotne zmiany do treści i formy pierwowzoru, przesuwając go znacząco w stronę kształtu, który znamy z gotowego dzieła.

\section{Opowiadanie a scenariusz literacki}

Opowiadanie wprowadza osobliwą konfigurację postaci głównych (komendant obozu trenuje z więźniem) i taki układ buduje mocną bazę dramaturgiczna, na której Hen tworzy psychologiczna, etyczna, aksjologiczną nadbudowę swej prozy. Musiał to sobie uświadomić Solan po przeczytaniu krótkiego utworu, odgadując jego filmowy potencjał.

Realizacja filmu jest najlepszym dowodem, do jakiej miary instynkt reżysera zadziałał prawidłowo. Kolejnym dowodem jest to, że fabuła w dużej mierze zachowuje konstrukcję pierwowzoru.

To prawda, że czas, który upłynął, we wspomnieniach twórców nanosi również możliwe osady niedokładności, zrozumiałe z perspektywy minionych dekad. Hen wspomina w rozmowie z Radomskim:

Słowacy nakręcili potem film na podstawie tego opowiadania. Józef Hen: Nakręcili, ale wcześniej trzy lata trwały targi, bo oni upierali się, żeby w tym obozie stworzyć organizację partyjną. Robili też wszystko, żeby na siłę uczynić z Kominka Słowaka. Takie to były czasy. Ale film powstał i w 1963 roku dostał w San Francisco nagrodę za humanistyczne treści. Czyli ja dostałem tę nagrodę, ale odebrał ją reżyser (śmiech) ${ }^{25}$.

Należy zaznaczyć, że nagrody w San Francisco nie otrzymał pierwowzór literacki, a dzieło filmowe i jego reżyser. To, że postacią główną w fabule słowackiej miał być Słowak, jest również zrozumiałe, zresztą narodowość głównego bohatera nie odgrywa kluczowej roli. Już z czysto praktycznych względów było naturalne, że główny bohater filmu mówi

${ }^{25}$ Józef Hen, Kiedyś oszustów w sporcie było mniej. 
po słowacku i nie ma potrzeby przekładać jego dialogów, zwłaszcza gdy tłumaczeń w tym filmie jest i tak już dosyć (z niemieckiego, polskiego).

Jeśli chodzi o organizacje partyjna, to ani $\mathrm{w}$ filmie, ani w scenariuszu z 1960 roku nie ma o niej nawet wzmianki. Prawdą jest, że w przeciwieństwie do opowiadania, do scenariusza i do filmu wszedł nowy motyw organizowania się grupy więźniów przygotowujących ucieczkę, ale nie jest on kluczowym elementem w strukturze dzieła, nie ma charakteru politycznego (a już na pewno partyjnego), staje się naturalną, organiczną częścią historii. Może nawet przyczynia się do głębszego rozgrzania, katalizowania niektórych relacji i wątków, tworzy odpowiednie sytuacje dramaturgiczne i konteksty.

Pewne starania o przemycenie "postępowych" idei znajdziemy jednak w scenariuszu z 1960 roku. Chodzi na przykład o hasło, jakie wygłasza Staszek ${ }^{26}$, przypomnienie jego przedwojennej nielegalnej partyjnej działalności w Warszawie ${ }^{27}$ i podobne ideologicznie motywowane wypowiedzi, których nie było w pierwowzorze.

Wróćmy do tematu twórczego procesu, jakim jest adaptacja, której interesującym etapem jest scenariusz. Pomysł wyjściowy oparcia opowiadania na relacji pomiędzy głównymi bohaterami doceniono w recenzjach:

Hen w swoim opowiadaniu wykonał ów decydujący krok, zerwał z faktograficznym, opisowym szeregowaniem obrazów z codziennej egzystencji w obozie, oderwał się od owej przerażającej banalności umierania, nie opiera siły przekazu na samych faktach, ale zmierza do syntezy i konfrontacji poprzez znaczący konflikt postaw - poprzez artystyczny wizerunek ${ }^{28}$.

Zachowanie tych walorów dostrzeżono również w filmowej adaptacji, w postaci, do jakiej przekształcił ją scenariusz literacki:

Scenariusz rozgrywa z konsekwentną precyzją z dowcipem i inteligencją wszystkie najdrobniejsze wątki sytuacyjne, nie wchodząc przy tym w niepotrzebne szczegóły i nie osłabiając głównego wątku i intencji dzieła. Można to wykazać na przykładzie indywidualnych, naświetlonych od wewnątrz psychologicznych reakcji bohaterów

${ }^{26} \mathrm{Na}$ stronie 61 scenariusza literackiego Staszek wypowiada konspiracyjne hasło z ideologiczną nutą: „Do obozu wiodą drogi z całej Europy. Wrócimy nimi jako wolni do domu!”. Tekst skreślony jest ręką Vichty i zastąpiony bardziej neutralnym: „Najpiękniejsze w świecie są czerwone róże. U nas rosną wolno".

27 "Gdybyś zapytał ludzi z warszawskiego przedmieścia, kim był Staszek, powiedziano by ci: nasz człowiek - komunista. Uparcie wierzył, że świat trzeba zmienić, aby można w nim było żyć po ludzku. Z powodu tej wiary tutaj się znalazł". Cyt. ze scenariusza, s. 73, ręką Tibora Vichty ta replika została skreślona.

28 Agneša Kalinová, Dôvera sa opláca, „Film a divadlo” 13.03.1963, nr 6, s. 8-9. 
w stopniowanych etapach scen boksu. Precyzyjna inteligencja w dialogu i rozwoju akcji daje nam szansę zapomnieć podczas projekcji filmu, że stopniowe narastanie siły więźnia Kominka pozwala już przewidzieć dalszy przebieg akcji ${ }^{29}$.

Chyba największa różnica pomiędzy opowiadaniem a scenariuszem tkwi w przyjętej ramie historii. Opowiadanie rozpoczyna się rozmową nieokreślonej grupy ludzi (przypomina to męską dyskusję w gospodzie), która odbywa się już w latach pokoju. Wybrane rozwiązanie kompozycyjne służy przede wszystkim przedstawieniu głównych bohaterów Kominka, Krafta i Helgi oraz Holdera, płynnie przechodzi do wojennych reminiscencji, z których już nie wraca do współczesności. Rudowłosy młodzieniec inicjuje rozmowę o Kominku:

Wreszcie ktoś przypomniał sobie: - Ach tak, Kominek, naturalnie... Bokser wagi półciężkiej. Widziałem go tuż przed wojną w meczu Rzeszów-Lublin. Wygrał swoją walkę przez k.o. Miał niezły cios. Czy jeszcze boksuje? Rudowłosy odpowiedział nonszalancko: - Powiedzmy, że jest prowincjonalnym działaczem sportowym. Chociaż zapowiadał się na mistrza świata ${ }^{30}$.

W ten sposób tekst od pierwszej strony zapowiada zakończenie historii. Kominek przeżyje, po wojnie funkcjonuje gdzieś jako działacz sportowy.

Największą różnicę pomiędzy opowiadaniem, scenariuszem i filmem znajdziemy w zakończeniu. O ile w opowiadaniu bokser po wygranej walce z komendantem opuszcza obóz i cieszy się pierwszymi chwilami wolności, a przenikliwy dźwięk syreny alarmowej dobiegający z obozu zachwieje jego dobrym samopoczuciem, to w scenariuszu (i w filmie) następuje wówczas najważniejszy gest bohatera. Decyduje się wrócić do obozu - z wielkim prawdopodobieństwem idzie na śmierć. Jest to naturalna konsekwencja rozwoju tej postaci. W opowiadaniu Hena zakończenie wygląda tak:

W dwie godziny później, gdy siedział w ciemnej knajpie nad kuflem piwa, uszu jego dobiegły dalekie dźwięki syren i poszczekiwanie psów.

- Oho - usłyszał głos bufetowego - Alarm w obozie. Ktoś uciekł. Jeden uciekł, czterdziestu pójdzie do pieca.

Pomyślał wówczas o obietnicy Krafta. Czy jej dotrzyma? ${ }^{31}$

Porównajmy to z zakończeniem w scenariuszu literackim (jego kształt odpowiada filmowi):

\footnotetext{
${ }^{29}$ Tamże.

${ }^{30}$ Józef Hen, Bokser i śmierć, Wydawnictwo Czytelnik, Warszawa 1975, s. 5.

${ }^{31}$ Tamże, s. 66.
} 
Ciszę przetnie przenikliwy głos syreny. Kominek spojrzy na dziewczynę. Wieśniak zdejmie kapelusz.

Idźcie! Wieczne odpoczywanie racz im...

Po twarzy Kominka przebiegnie przerażenie.

Kraft obiecał...

Kraft... powie wieśniak. Idźcie już!

Kominek wyjdzie na drogę, Halina za nim. Nie mogą wydobyć z siebie ani słowa. Kominek skręci w stronę obozu.

Wrócę... Przyszedłem pani tylko powiedzieć, że przygotowuje się nowa ucieczka. Żeby pani czekała...

I pan ucieknie?

Uśmiechnie się nieśmiało.

Spróbuję...

Odwróci się i idzie w kierunku obozu. Po twarzy ciekną mu łzy. Słychać dźwięk syren... ${ }^{32}$

\section{Scenariusz a film}

\section{Poziom adaptacji i samą realizację filmu docenił w swej recenzji Pavol Branko:}

Już w scenariuszu nakreślono wiele $\mathrm{z}$ tego bogactwa relacji. W pełni mogło się ono ukazać dopiero w specyficznej reżyserii Petra Solana, którego podejście charakteryzuje się odrzuceniem wszelkiej zewnętrznej stylizacji, tym, że nic nie dzieje się „przed kamerą", akcja rozwija się niejako samowolnie, bez „wygrywania” i natrętnego reżyserskiego ostrzegania widza: „teraz się mówi coś istotnego ${ }^{33}$.

\section{Również Václav Vondra docenił scenariuszowe i realizacyjne atry-} buty adaptacji:

34-letni reżyser Solan nie starał się w żadnym miejscu swej historii obozowej o wytworzenie typu modnego psychologiczno-intelektualnego filmu, choć scenariusz (J. Hen, T. Vichta, P. Solan) zmierzał trochę w tym kierunku. Solan od czasu swego pierwszego filmu nauczył się filmowego widzenia, precyzyjnego i wstrzemięźliwego, tak więc żadnej scenie nie można imputować innego znaczenia [...]. Przejrzysty i zrozumiały język filmu, emocje i ludzkie odczucia, odporność wobec jakichkolwiek konwencji i klisz - to niemała lokata, jaką zdeponował Solan w swym dziele, o którego realizację tak długo walczył z młodzieńczą wytrwałością ${ }^{34}$.

\footnotetext{
32 Józef Hen, Tibor Vichta, Peter Solan, Boxer a smrt', literárny scenár, jún 1960, s. 115.

${ }_{33}$ Pavol Branko, $V$ ringu s handicapom.

34 Václav Vondra, Solanův Boxer a smrt aneb slovenský film se omlazuje, „Práce” 11.04.1963.
} 
Wymowną wypowiedź reżysera przywołuje Richard Blech:

Nie chodziło mi o obóz koncentracyjny jako taki [...]. Chodziło mi o umiar, graniczący w pewnym sensie z dokumentalnością. Historia się dzieje, a kamera jakby znalazła się tam przypadkiem. Powstrzymywaliśmy się od zbędnych efektów i pewnie komuś mój film wydawać się może konserwatywny. Nawet to, co z filmowego punktu widzenia wydawało nam się efektowne, wycięliśmy przy montażu ${ }^{35}$.

Wspomniałem już o kluczowym znaczeniu paradoksalnej sytuacji więźnia Kominka, wybranego na sparring partnera komendanta obozu. Trójka współautorów precyzyjnie dopracowuje intencję pierwowzoru literackiego. Kulminuje się ona w samej fabule. Reżyser, świadomy siły środków filmowych, w mistrzowski sposób je wykorzystuje, osiągając ich nieprzeciętną ekspresyjność. Nie odwołuje się przy tym do nadzwyczajnych efektów, działa oszczędnie, bezpretensjonalnie - a zarazem „filmowo".

Na przykład już w tle napisów czołówki filmu jesteśmy świadkami uporczywego łomotania rękawic bokserskich w worek treningowy, ukazanego w jednym ujęciu. Stopniowo do dźwięków tępych uderzeń dochodzi w ścieżce dźwiękowej muzyka Wiliama Bukovego; sukcesywnie, z detalu rękawic, czarno-biały obraz powoli otwiera się i w szerszym ujęciu kamery widzimy korpulentnego boksera w trakcie indywidualnego treningu w małej siłowni. Filmowy sposób opowiadania przejawi się wyraźnie w scenie następującej po treningu: sportowiec znika za zasłona, aby przebrać się $\mathrm{w}$ „cywilne” ubranie. A wtedy następuje przemiana, którą można co prawda opisać również językiem literackim, ale w filmie, bez słów, można osiągnąć efekt nie do powtórzenia. Tekst nie jest w stanie przekazać tego, co potrafią migoczące kadry filmowe. Przy tym dzieje się coś na pierwszy rzut oka zupełnie banalnego: przed chwilą jeszcze sapiący sportowiec wyjdzie zza zasłony przebrany - tylko że w doskonale skrojony uniform esesmański; puentą tego ujęcia jest nałożenie na głowę czapki z trupią czaszką. Taki skrót ma sens jedynie w filmie, w opowiadaniu go nawet nie znajdziemy.

Solan rozważnie i precyzyjnie odwołuje się w całym filmie do specyficznego języka obrazu. Moglibyśmy znaleźć wiele przykładów, w których prosty, zwięzły obraz, często wspomagany grą aktorską wypowiada więcej niż tysiąc słów. Niewątpliwie należą tu również ujęcia milczącego, ponurego oblicza kapitana Holdera, kiedy Kominek znokautuje komendanta i wszyscy oczekuja, czy ten podniesie się przed końcem odliczania.

35 Richard Blech, Boxerov zápas nebol márny, s. 5. 
Doceniając walory realizacyjne, Pavol Branko mimowolnie przypomina o dość istotnym rysie tego filmu, jakim są wielojęzyczne dialogi postaci:

\begin{abstract}
Wspominaliśmy już o podstawowym reżyserskim kluczu tego filmu - mówić rzeczy istotne jakoś tak "półszeptem”, nie stylizować ich na koturny, budować na autentyzmie mowy środowiskowej. Autentyzm, który posuwa się tak daleko, że każda postać zachowuje swój indywidualny słownik, cechy językowo-charakterologiczne, które dzięki perfekcyjności interpretacji mają znaczny udział w kreowaniu sugestywności klimatu tego filmu, zwłaszcza dla tych, którzy potrafią smakować podstawowe składniki, perfekcyjną „esesmańską" niemczyznę, sudecką paplaninę pucybuta Williego i różnorodne słowiańskie poziomy wielonarodowej społeczności więźniów ${ }^{36}$.
\end{abstract}

Przypomnieniem wielojęzycznej realizacji filmu (z którą zasadniczo nie mamy do czynienia $\mathrm{w}$ opowiadaniu Hena, nie występuje też $\mathrm{w}$ formie literackiej scenariusza z czerwca 1960), wracamy do refleksji nad międzynarodowym charakterem dzieła, które jakkolwiek nie powstało według pierwotnie zamierzonej koprodukcji dwóch kinematografii socjalistycznych, ponieważ było to (paradoksalnie) nierealne ze względu na jego wysokie walory artystyczne i etyczne, ale jest dzieckiem autentycznej współpracy międzynarodowej twórców ze Słowacji, Polski i Niemiec, entuzjastów prawdziwej sztuki filmowej.

\title{
Bibliografia
}

\section{Archiwalia}

Hen Józef, Vichta Tibor, Solan Peter, Boxer a smrt', literárny scenár, jún 1960.

Výrobný list filmu Boxer a smrt', Archiwum Biblioteki SFÚ.

\section{Druki zwarte}

Bogacka Marta, Bokser z Auschwitz: losy Tadeusza Pietrzykowskiego, Demart SA, Warszawa 2012.

Hen Józef, Bokser i śmierć, Wydawnictwo Czytelnik, Warszawa 1975.

Kaňuch Martin, Podoby zvierat'a, stopy l'udskosti (Formy zwierząt, ślady ludzi), [w:] Slovenský film 60. rokov Boxer a smrt', DVD edícia Slovenského filmového ústavu a denníka Sme. Časopis DVD edície 04.

Macek Václav, Paštéková Jelena, Dejiny slovenskej kinematografie, Vydavatel’stvo Osveta, Martin 1997.

${ }^{36}$ Pavol Branko, V ringu s handicapom. 
Slovenský film 60. rokov: Boxer a smrt', DVD edícia Slovenského filmového ústavu a denníka Sme. Časopis DVD edície 04.

\section{Czasopisma}

Blech Richard, Boxerov zápas nebol márny, „Film a divadlo” 28.02.1963, nr 5.

Boxer a smrt' vo filme, „Večerník” 17.09.1959.

Branko Pavol, V ringu s handicapom, „Kultúrny život” 1963, nr 9.

Kalinová Agneša, Dôvera sa opláca, „Film a divadlo" 13.03.1963, nr 6, s. 8-9.

Karvaš Peter, Nejen tento film, „Rudé právo” 27.01.1963.

VondraVáclav, Solanův Boxer a smrt aneb slovenský film se omlazuje, „Práce” 11.04.1963.

\section{Źródła internetowe}

Józef Hen, Kiedyś oszustów w sporcie było mniej, http://www.przegladsportowy.pl/inne-dyscypliny,jozef-hen-kiedys-oszustow-w-sporcie-bylo-mniej,artykul,472898,1,307. html (dostęp: 2.05.2017).

Józef Hen. Życie i twórczość, http://culture.pl/pl/tworca/jozef-hen (dostęp: 26.05.2017).

\section{Streszczenie}

Autor obejmuje refleksją powstanie kultowego słowackiego filmu Bokser i śmierć, który młody reżyser Peter Solan zrealizował w 1962 roku, u progu czechosłowackiej nowej fali. Przygląda się uwarunkowaniom realizacji jako próbie koprodukcji w warunkach socjalizmu. Porównuje literacki pierwowzór, opowiadanie polskiego pisarza Józefa Hena, ze scenariuszem autorstwa polsko-słowackiego zespołu (Hen, Vichta, Solan) i z filmem, który powstał przy znaczącej współpracy artystów z Polski i Niemiec. 